\title{
STUDENTS' PERCEPTIONS OF SOME FACTORS INFLUENCING ACADEMIC ACHIEVEMENT AT A RURAL SOUTH AFRICAN UNIVERSITY
}

\author{
T. D. Sikhwari* \\ e-mail: tshimangadzo.sikhwari@univen.ac.za

\section{F. Ravhuhali*} \\ e-mail: fhatuwani.ravhuhali@univen.ac.za
}

\section{N. P. Lavhelani ${ }^{*}$}

e-mail: phellecy.lavhelani@univen.ac.za

\author{
F. H. Pataka* \\ e-mail: hlayisani.mboweni@univen.ac.za
}

${ }^{*}$ Centre for Higher Education Teaching And Learning

University of Venda

Thohoyandou, South Africa

\section{ABSTRACT}

The expansion of higher education in South Africa resulted in large numbers of tudents gaining access to universities. Research has shown that a major challenge facing higher education institutions is to enable students to succeed in their studies. The higher failure rate in higher education is an indicative of the need for various universities to investigate factors that influence student success. The present study explored participants' perceptions of factors influencing academic achievement. A qualitative design was adopted and open-ended questions were utilised for data collection purposes. The ten respondents ( 5 males and 5 females) for the study were conveniently sampled from a rural university in South Africa. Data were analyzed through content analysis. The results indicate that students'academic achievements are influenced by various factors, such as self-motivation, self-discipline, peer support, and lecturers' teaching approaches. The study concludes that there are variety of factors that impact on students' academic performance.

Keywords: higher education, perception, achievement, historically black institutions, factors, approach

\section{INTRODUCTION}

The higher education (HE) sector in South Africa has grown tremendously since the dawn of 
democracy in 1994.The expansion of higher education has resulted in enormous numbers of students from historically disadvantaged communities gaining access to universities. South African universities face a major challenge of enabling students to succeed in their studies within stipulated period. Frazer and Killen (2005) point out that the social, cultural and economic diversity of students who are enrolled in most South African universities, combined with the diversity of abilities, attributes and motivation, indicate that students may not achieve equally in their studies. According to Ntshoe (2002), there is a need for universities to investigate factors that influence student academic success. The Ministry of Education (2001) cautioned higher education institutions against opening access for disadvantaged groups for the sake of increasing student numbers. Fraser and Killen (2005) argue, in support of the Ministry of Education, that universities should ensure that they admit students who will be capable of completing the programmes in which they enrol.

Several authors such as Ngidi (2007), McKenzie and Schweizer (2001) express their opinions on the dominant trends in which the matric results are used as a way through which students are admitted in universities as well as the key and reliable predictor of how such students would perform academically in higher education institutions. Van Eeden and Tait (2002) argue against this claim, when they posit that the high failure rate in institutions of higher learning show that this claim is not absolutely true. Fraser and Killen (2005) argue that more attention need to be paid on variety of aspects that influence students' success in HE. Factors, such as students' family background (Mutsotso and Abenga 2010), lecturers' teaching approaches (Mlambo 2011), assessment tasks (McCann and Saunders 2010) and lecturer attributes (Shah 2009) have featured predominately in the literature focusing on students' success rates.

According to Ngidi (2007), the two studies which were conducted at the University of Pretoria and the University of South Africa and were aimed at investigating students' perceptions of factors that influence academic success found various major aspects that influence academic success of students. The factors include amongst others, self-discipline; family support; self-motivation; relevant assessment tasks; appropriate choice of course of study; relevance of course; self-confidence; systematic and wide-ranging feedbacks and pointers or comments on progress provided by lecturers; and commitment to a professional goal (Ngidi 2007).

The purpose of this study was to explore the perceptions of selected students with regard to their academic achievement at a rural university in South Africa. The study was aimed at finding answers to the following research questions: 
- How does family background influence students' performance?

- What measures do students take to achieve academic excellence?

- How do lecturers' teaching approaches influence student performance?

- How do assessment tasks influence student performance?

- How do degree choice and career aspirations influence student performance?

- In which ways do lecturer attributes (qualities) affect student performance?

\section{RESEARCH METHODS}

\section{Research design}

The study adopted qualitative research design to investigate perceptions of the participants on the phenomenon under investigation.

\section{Participants}

Convenience sampling procedure was used to select 10 participants from a list of 64 students who received Academic Excellence Awards at the rural university in South Africa in 2013, 2014 and 2016 academic years. Participants who were sampled were mainly students who readily were available and willing to participate in the study as the others had left to further their studies in other universities. The sample consisted of 5 males and 5 females. All 10 participants were in the 20-29 years age category; six participants were in their fourth year and 4 were at other levels of their postgraduate studies. Seven participants were residing on the university campus whereas three were in other forms of accommodation.

\section{Data collection procedure}

A self-constructed questionnaire was used for data collection purposes. The questionnaire had two sections. Section 1 was on biographical details of the participants while Section 2 consisted of open-ended questions based on issues such as family background, teaching approaches, assessment tasks and lecturer attributes. The questionnaire was pretested with 8 students before the actual data collection; these did not form part of the study. The questionnaire was pre-tested to help improve the quality of questions. The questions were based on the main research questions. The participants were given the questionnaires individually and requested to return the completed questionnaires within a stipulated period. The participants were also requested to complete an informed consent forms prior to filling in the questionnaires. Permission to conduct the study was sought from the Research Ethics Committee of the university. 


\section{Data analysis}

Data were analysed through content analysis as it is very suited to analysing narratives. $\mathrm{Du}$ Plooy-Celliers, Davis and Bezuidenhout (2014) indicate that content analysis entails a stringent and orderly set of measures or processes that are meant to ensure rigorous analysis, examination and verification of the contents of written data. The narratives were read repeatedly for the purpose of identifying units of meaning and common patterns.

\section{RESULTS}

The findings of this study are presented under 6 categories in line with the research questions.

\section{Category 1: Participants' views on family background}

Participants indicated that poor family background served as encouragement to work hard as expectations from family served as a motivation. Other participants indicated that what influenced their academic achievement is the kind of family support they received which was in the form of praises, incentives and words of encouragement. Participant 6 (P6) commented as follows regarding his background:

"I come from disadvantaged family and I was the first one to reach tertiary level. With the support from my family, I felt honoured to represent my family at tertiary level which motivated me to work hard since I didn't want to disappoint them. Since my family couldn't afford my tertiary fees, I was relying on NSFAS which also serve as a motivation to work even harder in order to ensure that I do not lose such funding opportunity. I must say that everyone from my family was expecting me to graduate of which I did with cum laude and made my family proud and to show them that the little they assisted me with in relation finance was a good investment."

Another participant (P9) indicated that self-motivation helped him as he always wanted to be the best and live well. He said the following:

"Frankly my background had no influence over my academic achievement, but I have been someone who always wanted to be the best and be outstanding in my academic work."

A female participant (P10) said that family expectations influenced her academic achievements.

\footnotetext{
"Basically I am the first born daughter in the family, the very first to go to university and everyone was looking at me to perform better and change the situation at home. So I worked hard from high school and became the best learner and when I enrolled here at the university, I worked hard in adapting to the new environment during my first year studying most of the time" (P10).
} 
Participant 8 is also from a very poor family background. In his family, no one has ever been to the university and that has served as a motivation to work hard. He commented as follows:

"I grew up in a very poor family. To my knowledge, nobody in my family ever made it to tertiary level where I am. This really affected my performance especially when I needed support in terms of certain resources. Even though they are poor, they supported me in any way they can so that I can be the success I am today."

\section{Category 2: Participants' views on measures to achieve academic excellence}

When participants were asked about what they did to achieve academic excellence, they highlighted several measures, such as being organised and self-motivated, studying and working hard, remaining disciplined and determined, having friends sharing the same vision, better utilization of time management skills and the importance of peer support and team work.

Participant 7 indicated that she was mainly motivated by her poor family background and the need to excel in life despite all the challenges. She explained that group discussions were very helpful, especially with regard to concepts that were very difficult to understand.

Participant 5 said that he had to study very hard during recess and was also lucky to have a brother who motivated him to study and work hard as well as support from peers. He added that he once failed one module during his studies due to the time-table, as both modules were scheduled for the same time; he had to choose one module over the other. He explained as follows:

"I overcame any failure by studying during recess, my brother was always motivating me to work harder while on the other side we use to encourage one another in our class to work very hard."

Participant 1 regarded his degree as the first priority in his life and he had a lot of self-discipline. He explained as follows:

"I got my degree in record time because it was my first priority. I had my time table for studying and stayed disciplined all the time. When I was doing my third year I was that person who did not believe in getting less than $70 \%$ in any of my tests."

Participant 3 indicated that support from the lecturers and a lot of hard work helped her succeed.

"The reason why I didn't fail it is because of hard work and efforts I put into my course during the semesters not forgetting the continuous support from lecturers and peers and teamwork."

Participant 2 wanted to retain the merit bursary awarded to her when she enrolled at the 
university. She said the following:

"I was using merit bursary which only paid $50 \%$ of my tuition fee and was rejected by NSFAS. This situation encouraged me to study very hard to maintain my 50\% merit bursary at all cost."

Participant 8 expressed the importance of choosing the right friend and how his friends inspired him to study hard. These friends played a crucial for him to excel academically. He explained as follows:

"I was born, raised and told "you are who you hang around with". At first I didn't understand but I followed the advice I got from my parents. I chose friends with similar vision as mine, thus, success. My friends always inspire me to study hard. We work together and participate in a positive competition with my friend. We always talk about success and victory and I strongly believe that what I am today is because of this positive friendship."

\section{Category 3: Participants' views on lecturers' teaching approaches}

Participants mentioned several aspects which enhanced their academic achievement in their degree programmes. These aspects include, amongst others, student involvement in class activities, supportive teaching environment, teaching aids and the use of tutorials. Some participants indicated that their lecturers' teaching approaches were appropriate, however, some of the lecturers seem to have lost the passion for their jobs. Participants expressed how they engaged with their lecturers throughout their studies and were able to do well once they understood the lecturers' approaches to teaching. Participants 4 and 8 said that their lecturers' teaching approaches were such that they were able to understand what was done in the class and what was expected in tests and examinations. They commented as follows:

“The lecturers' approaches towards teaching were commendable and have helped me to do well and pass all the modules in my field. The lecturers would give us all the resources relevant to our degree or course programme in order to help us understand the concepts much better. Each lecture was deliver in accordance to the course outline in an appropriate venue and everything was completed within the stipulated time. Things like lesson slides were made available to all of us in time through blackboard" (P4).

"In most of my lessons I followed how each lecturer require things to be done. I know all my lecturers' ways of emphasizing things in the class. Some lecturers are just perfect and I just have to pay attention. I have discovered that lecturers are different and so they use different approaches and styles. The secret I discovered is that one has to adjust to each style of our lecturer" (P8).

Participant 10 indicated that she found the modules easy to do from the first semester. She expressed herself as follows: 
"First year programme was not much of a problem as it was a continuation of what we did in high school. Although most of our classes were having more than hundred students, our lecturers always made sure that we understood everything very well. Most of our lecturers interacts well with us as students and makes us feel good in our class and learning become enjoyable."

Participant 9 emphasized how problem-based learning helped her to understand better in class.

"Lecturers' approaches in teaching has really been contributing so much to my academic achievements especially the teaching method that my department used which is problem-based learning (PBL). This teaching method has been helpful since it made me to be greatly involved in my own learning."

\section{Category 4: Participants' views on assessment tasks and feedback}

Participants were asked to explain what their views are with regard to assessment tasks and feedback they received on the tasks. Participants indicated that a lot of exercises and assignments they had to write were helpful and that timeous feedback encouraged learning, and enhanced the understanding of content. One of the participants indicated that assessment tasks helped him to improve on his research skills. Participant 6 indicated that assessment tasks and feedback he used to get were helpful in identifying his strengths and weaknesses. That has helped him to improve on his performances in both tests and assignments including, examinations. He commented as follows:

"They helped me see my weaknesses and strengths which I used to improve during the next assessment or exams. Regarding tasks such as oral presentation, I improved on aspects such as standing in front of the people ...." (P6).

Participant 1 commented as follows about assessment tasks and feedback in support of P6:

"Our lecturers always made use of assessment tasks to make us understand more what they are teaching us while feedback gave us a good and clear understanding of our module content."

What P6 and P1 said were supported by participant P10 who indicated the following:

"Tests and assignments given to us were fair and understandable and helped me to do well in all of my modules."

Participant 7 also added the following about feedback:

"Test feedback helps me to see where I have to improve and to do even better. I am one person who always want to do well in my studies and to be the top student. So if there is someone in our 
class who get higher marks than mine, it gives me more courage to work and study much harder in order to make sure that I do better in the next test or assignment task."

\section{Category 5: Participants' views on degree choice and career aspirations}

Even though the career guidance that participants received was inadequate, they had a positive attitude towards their chosen degrees and this enhanced their understanding. Participant 1 indicated that he came to the university not knowing exactly what he was going to do, but once he was introduced to the BScMST degree programme, he immediately liked it. Participant 6 had an opportunity to visit the Agriculture Research Council (ARC) while he was in high school. At the ARC he met potential researchers in the field of agriculture and that had inspired him to enrol for the degree. All the participants expressed different career aspirations with a number of them wanting to be researchers in their field of study. The following is what participants said about their degree choice and career aspirations:

"The degree itself gives me much inspirations each and every morning to be at my best with all my academic achievements. Also the scope of the practice inspires me because after all, I love working with people and Biokinetics have really given me a chance to interact with people in a way that I have never imagined" (P9).

"I did Food Science degree due to my love of food and to understand food processing. For the degree was not difficult at all because I was in love with it and was doing something that I find interesting" (P5).

"The love that I have for my degree influenced me to stay focused as I am doing what I want and love. I spent a lot of time trying to learn to understand it much better. I have big plans and can't wait to be where I always wanted to be" (P7).

"From the first year I wanted to do a different degree (nursing) but I ended up doing another degree (Agriculture Plant Science) which I never thought of in my life as it was not even my second or let alone my third choice mainly due to lack of space in my preferred programme. To my surprise, I find myself excelling in my degree programme and I ended up being the best student during my first year of study. It has really inspired me to even do much better and now I am planning to do a research and be a researcher in plant pathology" (P10).

\section{Category 6: Participants' views on lecturer attributes (qualities)}

With the exception of participant 6 who attributed his academic achievements to talent, hard work, dedication, motivation from friends and family, other participants indicated that their achievements were made possible by their lecturers. Participants' views on lecturers' attributes or qualities were very positive. Participants expressed how their lecturers were organised and knew their subject matter, and the fact that they possess good communication skills, were always friendly and available for students, were approachable as well as encouraging, as qualities which aided students' success. Another factor mentioned by participants was the fact that a vast number of their lecturers have doctoral degrees and were either senior lecturers or 
professors. Participant 1 expressed his views on lecturer attributes as follows:

"Most of my lecturers who taught me have a good qualities for an example self-control and organised, possess interpersonal and communication skills."

This was supported by P4 who indicated that her lecturers knew their subject matter and were very helpful.

"The lecturers knew what they were teaching and have always assisted us with anything we require from them. They were very friendly and encouraging and always made efforts to ensure that students are able to understand everything concerning the modules."

Participant 8 indicated that he is grateful that all his lecturers from his Department were friendly and always approachable.

"I found lectures' attitude have been a key factor in my learning. I thank God for my department because of the spirit we have. We have the friendliest lecturers ever. Even though people' qualities may never be the same, our lecturers were able to create a conducive learning environment for everyone. Above all, they were approachable, audible during our classes and they take their work serious."

Participant 10 was also full of praise for her lecturers with an exception of one lecturer who taught her Chemistry during her first year who, instead of motivating the students, he discouraged them. The lecturer scared all the students. She commented as follows about her lecturers:

"Most lecturers in our classes showed good qualities such as interpersonal and communication skills which made it easier for us as students to participate in class. But the lecturer who was teaching Chemistry during the first year did not give motivation from the first day but instead he mentioned that Chemistry is the most difficult and failed course in the university."

Participant 7 commented about his lecturers as follows:

"Some lecturers makes difficult modules to be interesting thereby making it easier for students to invest their time on such modules. And also assessment tasks given to us such as assignments and presentations made us to be more interested to the modules and to understand the modules better as you are given an opportunity to go and get some information on your own."

Agreeing with the other participants, P3 mentioned the following with regard to lecturers' attributes: 
"The lecturers were more involved in the academic progress of all the students. They were always available to assist students, always motivated students to work harder and provide feedback on time. They also assisted when they thought students are not necessarily doing well. They also created environment which ensure that students are able to work very hard from the beginning of the semester until we wrote exams."

\section{DISCUSSION}

\section{Family background and students' academic achievement}

Poor family background might be considered an effective inspiring and motivating element for students to work hard and achieve academically as shown in this study. Some of the aspects that arose from the findings is that participants did not want to disappoint their parents; others value family expectations as crucial in their academic achievement. The findings from a study by Osuafor and Okonkwo (2013) revealed that the way families are structure and parental occupations as well as their educational level had little influence on academic achievement of students. The authors indicated that their result was in contrast to previous studies conducted on the subject. Ebong (2015) similarly note that, academic achievement of students was not dependent on family structure, parent occupation or their educational levels. Al Shawwa et al. (2015) also found that factors such as family possessions and financial status were insignificant in the academic achievement or performance of students. Weiser and Riggio (2010) opine that students' home background loses its significance as students grow older, and therefore, it would be difficult to say that it does not have any influence, especially in the last years of students' secondary school. Even though these studies provide findings that are not in line with findings of this current study, it is worth noting that variety of issues or aspects can influence students differently towards their academic achievement. Weiser and Riggio (2010) suggest that in relation to students, self-efficacy is one of the strongest and constant predictor of students' academic performance and success.

\section{Measures to achieve academic excellence}

Alos, Caranto and David (2015) identify measures that are critical for students to achieve academic excellence as mostly teacher-related aspects which have to do with how they teach and engage students. In addition, Alos et al. (2015) maintain that students' study habits and school-related aspects also have an impact on their academic achievements. In line with the findings by Osuafor and Okonkwo (2013) and Ebong (2015), personal conditions and homerelated aspects were found to have little or no impact on students' academic excellence. Ali et al. (2013) highlight that factors of importance to students' academic achievement include age, 
father/guardian socio-economic status and daily study hours. Gajghat, Handa and Himte (2017) lists students' personal characteristics, learning habits, previous academic background and the colleges' environmental factors as some of the aspects that influence students' performance of at university level. Gajghat et al. (2017) argue that these factors might be equated to students' performance and academic achievement while another school of thought puts personal characteristics and learning habits as the most significant determinants as compared to previous academic background and college environmental features. Al Shawwa et al. (2015) isolated a strong motivation for achievement and a clear goal as being some of the aspects that contribute towards students' academic achievement.

Al Shawwa et al. (2015) argue that utilising noiseless and conducive space coupled with note making such as speed-reading or browsing tend to have positive effects on better students' academic achievement. Al Shawwa et al. (2015) also mention attending or using problem based learning (PBL) sessions as well as studying for more hours on the weekends also contribute immensely on students' academic achievement. Other aspects or factors such as lectures attendance and spending a lot of time studying during the weekdays were found to be less significant in influencing students' academic achievement (Al Shawwa et al. 2015). Fraser and Killen (2005) found that if students are self-motivated, making concerted efforts and have a will power to succeed, that can impact positively on the students' academic achievement. They continue by pointing out that lecturers have a responsibility to help all their students to be successful in their studies. Self-discipline and self-motivation were found to be some important factors contributing to students' success (Fraser and Killen 2005). Through such motivation, their behavioural patterns changed resulting in engaging themselves with their academic work to ensure excellence in what they do.

\section{Lecturers' teaching approaches}

Shaaria et al. (2014) study found that there is substantial yet modest relationship between the teaching style used by lecturers and how students engage well academically. Ganyaupfu's (2013) study suggests that teacher-student interactive and student-centred approaches were found to be more effective teaching methods compared to teacher-centered approach. Khandaghi and Farasatb (2011) posits that learner-centred teaching style always lead to students' emotional, social and educational adaptation to the learning situation. Khandaghi and Farasatb (2011) recommend the use of some new teaching styles or approaches bearing in mind the interest of students and their diversity in order to maximize their potential. Apart from teaching methods that lecturers might apply in their class, Shaaria et al. (2014) stress that lecturers should create an environment suitable for student engagement. It is upon this finding 
that Shaaria et al. (2014) recommended that universities and the lecturers provide a positive teaching and learning environment. Iureaa, Neacşub, Saftac, and Suditud $(2011,260)$ advice that "a good teaching method is the one that implies relevant and visible training values which shall motivate students and make them aware of their understanding and reflection, help them make up their critical thinking which will guarantee their trust in their own forces, thus becoming capable of deep understanding of ideas and schemes, as well as the modalities of connecting these with the values and the skills required by their future jobs". This would indicate that for a teaching method to be effective, it should provide platforms on which students do not only receive the content but are active and critical participants in their own learning. Mlambo (2011) argues that the learning preference of students and the teaching style adopted by lecturers tend to have positive impact on the performance of students at university. Mlambo (2011) further states even though the topics that are discussed in classes might be less interesting, students may still be motivate to attend for as long as the lectures is able to bring about variety of active learning methods or tactics while teaching.

\section{Assessment tasks and feedback}

A lot has been written about assessment and the importance of feedback. A study by Trotter (2006) concludes that students are often very positive about the use of continuous, summative assessment and that students were extrinsically motivated to undertake such assessment tasks. Moreover, their engagements with such assessment may result in a learning environment that encourages group discussions and practice, which in turn inspired students to excel in their studies (Trotter 2006). Ramsden (1994) outlines two functions of assessment which are to inform us whether or not learning was successful and to alert and inform students what they need to learn. Luckett and Sutherland (2000) indicate that assessment always provide the needed feedback to students in relation to their progress as a way to motivate them as well as assisting them to improve their own learning. Luckett and Sutherland (2000) argue that for the feedback to be most effective, it is incumbent on students who receives it to be proactive in using that to identify gaps and to bring about new ways of learning (Luckett and Sutherland 2000). Race (2002) contends that for the feedback to be effective, it has to be provided timeously especially in computer-aided learning situations.

\section{Degree choice and career aspirations}

Quaglia and Cobb (1996), in Hafsyan (2015), highlight that students' desires and choice of a degree can be influenced by the interaction between personal factors which may include student's ability and self-efficacy, and environmental factors in which the students are, which 
include peer influence and school setting. Moreover, adolescents who harbour expectations of success are more likely to actually thrive, especially when their academic abilities facilitate their success (Hafsyan 2015).

Participants in this study indicated that the choice of a particular degree inspired them to work hard in pursuance of their chosen career. Hafsyan (2015) states that educational and career aspirations revolve around the ambition and inspiration of a student. Quaglia and Cobb (1996, 130) defined ambition as "the perception that an activity is important as a means to future goals". If, for example, a student has a desire to achieve an outcome, then he or she will be more ambitious and strive to attain his or her goals. Quaglia and Cobb $(1996,130)$ add: "inspiration reflects that an activity is exciting and enjoyable to the individual and the awareness of being fully and richly involved in life here and now". Hafsyan (2015) posits that inspiration is a vital component of aspiration because students seek to do what they enjoy. Hafsyan (2015) further explains that ambition requires both drive and determination and encouragement since ambition provides the desire to work and inspiration provides a way in which a particular assignment can be carried out. For example, students work hard in all the subjects they enjoy in order to do well academically while at the same time focusing on their career aspirations.

\section{Lecturers' attributes (qualities)}

Expected lecturers' attributes by students are that, they had to be well organised and well conversant with their subject matter, always friendly and encouraging, available for students as well as being approachable. These views are consistent with Ramsden's (1994) principles of good teaching. Ramsden (1994) identifies six principles associated with good teaching in higher education or university. Firstly, there is interest and explanation principle which essentially means that lecturers need to explain clearly all the subject matters that are difficult and complex for learners to understand. This is said to be the mandatory part of the lecturer's repertoire and should result in sparking students' curiosity to ensure that students are actively engaged by challenging and creative expectations (BBC Active nd.). Secondly, there is concern and respect for students and student learning. Lecturers are not expected to frighten students or demonstrate aggressiveness, stringency, and inflexibility in their interactions with students. This is closely linked to respecting students' learning style and being able to listen to their feedback (BBC Active nd.). Thirdly, there is the principle of appropriate assessment and feedback which calls for lecturers to set appropriate assessment tasks as it is a crucial aspect in ensuring that students are able to maximize their learning and development. This should also be fostered by providing or giving genuinely helpful feedback on the work of students. The fourth principle is clear goals and intellectual challenge. Ramsden (1994) emphasized the need for lecturers to set clear goals 
and intellectual challenge for their students by setting high academic expectations which tend to yield high levels of students' performance. The fifth principle is that of independence, control, and active learning. Lecturing of students should be done in such a way that students are able to engage with the tasks they are learning in order to ensure that they are able to understand better. This would certainly ensure that students are able to have control over their own learning. The sixth principle is that of learning from students where lecturers are cautioned not to take their students for granted. This would indicate that lecturers need to see and acknowledge that they are in teaching and learning partnership with their students. Effective teachers do not take their students for granted. Lecturers need to understand that any decent teaching is subject to changes and modifications, and most importantly, should be characterised by different modifications and changes to locate how effective it is in bringing about successful students' learning.

Most of the participants indicated that the lecturers had a positive attitude and this has been a key factor in creating an environment conducive to learning. A study by Fazio and Roskes (1994) found that attitude consist of both cognitive and emotional components, all of which influence the way in which teachers reflect and reacts to varying experiences. Eggen and Kauchak (2001) maintain teachers' positive attitudes are vital in regard to effective teaching and academic achievements of students. Bruning et al. (1999) identify various components which make up teachers' attitudes while at the same time creating a caring and supportive classroom environment. The elements include amongst others, caring, enthusiasm, teaching efficacy, constructive interaction with students, and high expectation to promote students' motivation (Bruning et al. 1999). All these factors as also shown in this study, are associated with an increase in students' academic performances.

\section{IMPLICATIONS OF THE STUDY AND CONCLUSION}

It is worth noting that the study was conducted with a small sample, therefore caution should be taken in generalizing these findings to other groups. Moreover, as the findings were based on perceptions of personal experiences, therefore, bias as a result of incorrect interpretation of the questions by the participants could have occurred. Bias might also be influenced by the participants' possible desire to give educationally desirable responses.

Notwithstanding the limitations, the study found that motivation, interest in the degree, family expectations, self-discipline and peer support are some of the factors that influence students' academic success. These factors are, however, interdependent and differ from one individual to another, as students come from diverse social, cultural and economic backgrounds. In addition, the study found that teaching approaches and lecturer attributes have an impact on 
academic performance of students. The University should, therefore, adopt a holistic approach when developing and implementing academic support programmes so that they can be effective, especially for first year students who are presumed to be in a difficult transition period. It is also important that the University should step up the professional development programs to capacitate university teachers or lecturers in order to ensure that their teaching practices is enhanced. This would also bring about changes in their overall attitudes and beliefs which are all crucial for students' learning outcomes.

\section{REFERENCES}

Ali, S., Z. Haider, F. Munir, H. Khan and A. Ahmed. 2013. Factors contributing to students' academic performance: A case study of Islamia University sub-campus. American Journal of Educational Research 1(8): 283-289. DOI: 10.12691/education-1-8-3.

Alos, S. B., L. C. Caranto and J. J. T. David. 2015. Factors affecting the academic performance of student nurses of BSU. International Journal of Nursing Science 5(2): 60-65. DOI: 10.5923/j.nursing.20150502.04.

Al Shawwa, L., A. A. Abulaban, A. Merdad, S. Baghlaf, A. Algethami, J. Abu-Shanab and A. Balkhoyo. 2015. Factors potentially influencing academic performance among medical students. Advances in Medical Education and Practice 6: 65-75.

Astin, A. W. 1999. Student involvement: A developmental theory for higher education. Journal of College Student Development 40(5): 518-529.

BBC Active. nd. "What makes a good lecturer? Here are our top 20 Tips for New Lecturers." http://www.bbcactive.com/BBCActiveIdeasandResources/Whatmakesagoodlecturer.aspx. (Accessed 21 November 2017).

Bruning, R., G. Schraw and R. Ronning. 1999. Cognitive psychology and instruction. $3^{\text {rd }}$ Edition. New Jersey: Prentice Hall.

Du Plooy-Cilliers, F., C. Davis and R. Bezuidenhout. (Eds.). 2014. Research matters. Cape Town: Juta.

Ebong, S. T. 2015. The influence of parental background on students' academic performance in physics in WASSCE 2000-2005. European Journal of Science and Mathematics Education 3(1): 33-44.

Eggen, P. and D. Kauchak. 2001. Strategies for teachers: Teaching content and thinking skills. $4^{\text {th }}$ Edition. Needhan Heights: Allyn and Bacon.

Fazio, R. H. and D. Roskes. 1994. Acting as we feel: When and how attitudes guide behaviour. Boston: Allyn and Bacon.

Fraser, W. and R. Killen. 2005. The perceptions of students and lecturers of some factors influencing academic performance at two South African universities. Perspectives in Education 23(1): 25-40.

Ganyaupfu, E. M. 2013.Teaching methods and students' academic performance. International Journal of Humanities and Social Science Invention 2(9): 29-35.

Gajghat, R. H., C. C. Handa and R. L. Himte. 2017. Factors influencing academic performance of the students at university level exam: A literature review. International Journal of Research in Engineering and Technology 6(05): 102-110.

Hafsyan, A. S. 2015. Educational and career aspirations of university honors and non-honors students. Doctoral Dissertations. http://digitalcommons.uconn.edu/dissertations/687

Iureaa, C., I. Neacşub, C. G. Saftac and M. Suditud. 2011. The Study of the relation between the teaching methods and the learning styles: The impact upon the students' academic conduct. Procedia Social and Behavioral Sciences 11: 256-260.

Khandaghi M. A. and M. Farasatb. 2011. The effect of teachers' teaching style on students' adjustment. 
Procedia Social and Behavioral Sciences 15: 1391-1394.

Luckett, K. and L. Sutherland. 2000. Assessment practices that improve teaching and learning. In Improving teaching and learning in higher education: A hand book for South Africa, ed. S. Makoni. Johannesburg: Witwatersrand Press and HERDSA.

McCann, L. and G. Saunders. 2010. Exploring student perceptions of assessment feedback. The Higher Education Academy: 1-7.

Mckenzie, K. and R. Schweitzer, 2001. Who succeeds at university? Factors predicting academic performance in first year Australian university students. Higher Education Research and Development 20(1): 21-33.

Ministry of Education. 2001. National plan for higher Education. Pretoria: Ministry of education.

Mlambo, V. 2011. An analysis of some factors affecting student academic performance in an introductory Biochemistry course at the University of West Indies. Caribbean Teaching Scholar 1(2): 79-92.

Mutsotso, S. N. and E. S. B. Abenga. 2010. Study methods for improving quality learning and performance in higher education. Education Research and Review 5(12): 808-813.

Ngidi, D. P. 2007. Students' and lecturers' perceptions of some factors influencing students' academic success or failure at a historically black university in South Africa. South Africa Journal of Higher Education 21(4): 717-732.

Ntshoe, I. M. 2002. National plan for higher education in South Africa: A programme for equity and redress or globalised competition and managerialism? South African Journal of Higher Education 16(2): 7-10.

Osuafor, A. and I. Okonkwo. 2013. Influence of family background on academic achievement of secondary school Biology students in Anambra State. African Research Review 7(3): 156-167.

Quaglia, R. J. and C.D Cobb. 1996. Toward a theory of student aspirations. Journal of Research in Rural Education 12: 127-132.

Race, P. 2002. Using feedback to help students to learn. The Higher Education Academy. http://philrace.co.uk/achieve-of-downloads-from-previous-website/ (Accessed 28 November 2012).

Ramsden, P. 1994. Learning to teach in higher education. Cornwall: TJ International Ltd.

Shaaria, A. S., N. M. Yusoff, I. M. Ghazalic, R. H. Osmand and N. F. M. Dzahir. 2014.The relationship between lecturers' teaching style with the students' academic engagement. Procedia-Social and Behavioral Sciences 118: 10-20.

Shah, S. S. A. 2009. Impact of teachers' behaviour on the academic achievement of university students. Pawalpindi (Pakistan): Pirmchr Ali Shar Arid Agriculture University.

Trotter, E. 2006. Student perceptions of continuous summative assessment. Assessment \& Evaluation in Higher Education 31(5): 505-521. DOI: 10.1080/02602930600679506.

Van Eeden, S. and M. Tait. 2002. An exploratory study on the perceptions of previously educationally disadvantaged first-year learners of law regarding university education. South African Journal of Higher Education 16(2): 177-182.

Weiser, D. A. and H. R. Riggio. 2010. Family background and academic achievement: Does selfefficacy mediate outcomes? Social Psychology Education 13: 367-383. DOI 10.1007/s11218-0109115. 